\title{
Foreign Direct Investment in Russia: Stakeholders' Views and Perceptions
}

\author{
Nadejda Komendantova ${ }^{1,2}$, Leena Ilmola ${ }^{1}$, Anastasia Stepanova ${ }^{1}$ \\ ${ }^{1}$ International Institute for Applied Systems Analysis (IIASA), Austria \\ ${ }^{2}$ Institute for Environmental Decisions (ETH), Switzerland \\ *komendan@iiasa.ac.at
}

\begin{abstract}
Volumes of foreign direct investments (FDI) are growing steadily, however, transition economies, such as Russia, are attracting only a minor share of FDI despite of available potentials. Risk aversion is one of the reasons influencing decision-making processes of FDI investors. This paper reviews existing objective and subjective risks, which impact decisions regarding FDI. The results of the paper are based on the extensive dialogue with stakeholders from Austria, Germany and Japan on the risks for FDI in Russia as well as on the outcomes of the discussions on barriers for trade in frames of the workshop, which brought together Russian and European stakeholders. The results show that political, regulatory, revenue, currency and operational risks within the economy of Russia are perceived by FDI investors from different sectors such as construction, financing, automotive and other industries as being the most likely and probable risks for FDI in Russia. The majority of investors perceive political risks as a greater barrier for investment in Russia. These perceptions are influenced by existing asymmetries on the market and the political decision-making dominance over business environment. Our results support existing evidence on impacts of uncertainties connected with political and regulatory risks for FDI in Russia. However, we did not find evidence that these risk perceptions were affected by creation of the Eurasian Customs Union, neither in positive nor in a negative way. The results suggest that significant progress was already done by improving investment climate in Russia but further efforts are also needed on addressing regulatory risks such as dealing with construction permits, protecting minority investors or simplifying customs regulations, as well as addressing existing market asymmetries.
\end{abstract}

Keywords: Foreign direct investment, transition economies, decision-making processes and risk aversion

\section{Introduction}

Foreign direct investment (FDI) contributes to modernization of economy of hosting country because they are connected with technology transfer. With investment into advanced technologies new ideas are transferred from the source to the host country, which increases competition and improves efficiency, by lowering prices to consumers (Dunning, 1973). The effects of FDI on economic growth in transition economies were tested by Campos and Kinoshita (2002), which found significant positive effects. However, this effect will depend on the quality of institutional framework in the hosting transition countries (Jude and Levieuge, 2014). During the last decades the volumes of international trade and FDI were growing significantly globally mainly due to favorable economic climate and orientation of private sector towards geographical reorganization of production. Only in the period between 2000 and 2010 the volumes of the world trade increased from 48\% to 58\% (UNCTAD, 2010) and the period 1985-1990 saw the fastest FDI growing economic activity. In this period FDI increased from an average of 142 billion dollars US in 1985 to 1.2 trillion dollars US in 2010 (UNCTAD, 2014). The turbulent period of financial crisis resulted in a certain declaim of FDI, those volume is however, growing since 2015. In 2014 UNCTAD conducted a survey in collaboration with McKinsey among 1.000 top managers in 89 countries. $42 \%$ of them think that the state of development in transition economies, as well as regional economic integration (37\%) will lead to an increase of FDI globally. Also $63 \%$ of them think that FDI into transition economies will be increasing in the period between 2015-2017.

FDI make an important share of financing volumes in transition economies and account for $40 \%$ of external development finance in these countries (UNCTAD, 2015). The year 2014 saw a record decline in FDI by 52\% in comparison to the previous year, mainly, because of regional conflicts, falling oil prices and international 
sanctions, according to the World Investment Report. The drop of FDI in some of the transition economies, such as Russia, was even more dramatic and made 70\% in 2014 comparatively to 2013 . The dynamics of FDI show that significant growth of FDI activities can be followed by drastic declines and that this dynamic depends on decision-making process of investors, which is influenced by their vision of existing risks for their investment. Majority of existing on FDI works tell that the decision of foreign investors to undertake FDI depends, mainly, on economic factors and favorable institutional environment in the hosting country (Dunning, 1998). Since late 1990s several works were written on FDI in transition economies, mainly, using statistical methods of analysis and focusing on quantifiable impacts from FDI. The works on qualitative factors, such as impacts of cultural determinants or human factors, including views, concerns and perceptions of stakeholders, are almost non-existent (Lucke and Eichler, 2016).

At the end of the 2000ies Russia became one of the largest recipients of FDI among the Central and Easter European (CEE) countries. The cumulative gross direct investment in Russia from 1989 to 2009 was 24 billion USD higher than the amount received by Poland, which was the second largest FDI recipient among the CEE countries (UNCTAD, 2015). Until now little research was conducted on barriers for FDI in Russia, which can be explained by two reasons, such as on-going transition from centralized market structures towards market economy and the fact that the region started recently attracting FDI (Azam and Ahmed, 2015). Also Iwasaki and Tokunaga (2014) found out that the works on post-communist transition economies account only for a very small proportion of earlier studies, with the majority of these studies being focused on the Central and Eastern European countries, which joined the European Union. Only a very small portion of existing research is focusing on Russia and other countries of the former Soviet Union.

In this paper we argue about the importance of understanding human factors, such as risk perceptions, and their impacts on decision-making processes regarding FDI. Following the distinction of Slovic (1987), we assume that there is a difference between existing risks, such as unstable institutional environment, and perceived risks, which can be subjects of cognitive and behavioral biases. We choose Russia as our case country for several reasons. First, this is one of the largest transition economies, which before the year of 2014 was the third most attractive place for FDI investment among transition countries. Evidence also exists that FDI have significant positive effects on the economy of Russia, at the same time, as these effects are less significant in other countries of the region. For instance, Iwasaki and Tokunaga (2014) find significant positive effects of FDI on total factor productivity in the Russian regions and the remarkable role of FDI in the regional economic development of Russia. However, Ahmed and Azam (2015) found weak statistical evidence of positive effects of FDI on economic growth of other countries of the region, not only because these countries were not able to attract desirable volumes of FDI but also due to uncertainties and economic disturbances in the last years. Second, because Russia currently experienced a number of developments, which might have impacted perceptions of FDI investment in this country. Third, we were interested how FDI investment were impacted by risk perceptions, connected with cultural environment of the country rather than with objective risks.

\section{Literature Review}

Impacts of objective and subjective factors on FDI decisions: In our research we focus on two groups of factors, which influence decisions of FDI investors. The first group of factors, the so-called "objective factors", is characterized by trading relations and international framework influencing these relations. We include into this group such factors as trade integration. Previous studies identified positive and robust correlation between trade integration and FDI activity, when FDI were often described even as a "new engine" of economic growth for recipient countries (Kobrin, 2005). The liberal market economy theorists tell that the optimization of resources requires free capital and investment flows. For example, Martinez-San Roman et al. (2015) examined patterns of FDI flows within the European Union and impacts of trade integration on these flows over the period 1995-2009. Also foreign economic relations can become a catalyst of economic transformation where trade agreements would restructure economy, markets and their dynamics and contribute to the accumulation of capital. The study on the impacts of the Eurasian Customs Union found that trade barriers limiting FDI have impacts on economic growth (Mkrtchyan and Gnutzmann, 2014). The links between FDI and trade were also identified by Pfaffermayer (1996), Brainard (1997), Blonigen (2001), Neary (2009). For some countries the effects on FDI could be solely explained by how easy it is to trade across the 
borders, at the same time as other components of ease of doing business have little or no effects on FDI. Also for the middle-income countries, like Russia, being in a cluster of countries with good trade regulations improves their ability to attract FDI.

The second group is so-called "subjective factors", which are cultural or human factors characterizing the business environment. These factors represent perceptions of specific characteristics of the hosting country. Research showed that regulatory reforms leading to more liberalization, particularly, in relations to the markets entry, lead to perceptions of regulatory environment as being more attractive and an increased FDI activity (Alesina et al., 2005) and, in contrary, costly entry regulations reduce the number of newly created firms (Klapper et al., 2006). Martinez-San Roman et al. (2015) identified several factors, which affect perceptions of investors and make one country looking more risky for investment in contrary to another one. These factors are quality standards, bureaucracy, regulations and complexity of contracts as well as consumers preferences. Significant correlation also exists between perceptions of business environment of the host country, which is reflected by the Ease of Doing Business Index, developed by the World Bank, and the volumes of FDI. For instance, Jayasuriya (2011) finds that higher Doing Business ranking impacts risk perceptions of investors and attracts more FDI. At the same time, Corcoran and Gillanders (2015) find significant influence of Doing Business rank of a country on perceptions of regulatory environment and on investment decisions. There are also many other factors, which influence risk perceptions such as perceptions of quality and complexity of bureaucracy (Busse and Hefeker, 2007; Komendantova et al., 2011), generic host bureaucratic quality (Eicher et al., 2011) or tax complexity (Lawless, 2009). Other studies speak also about such cultural factors as perceptions of corruption risks or impact of religion (Egger and Winner, 2005) and cultural distance to a host country, such as common religion, language, border and similar past with hosting country (Lucke and Eichler, 2016). Another important factor is the social infrastructure and evidence shows that FDI are mainly attracted by the countries, which have strong social infrastructure (Hall and Jones, 1999) and can include well-functioning state institutions and stable governments (Janjua and Samad, 2007).

Current situation in Russia: In the last decades several types of trade liberalization and integration models were introduced, affecting also trade with Russia. The first type is free trade agreements, which are concluded on the bilateral basis. The second type is regional integration bloc, for example, the Customs Union (CU) of Belarus, Kazakhstan and Russia, which resulted in abolition of customs regulations between these three countries. On January 1, 2012 the three states of Russia, Kazakhstan and Belarus formed a Single Economic Space (SES) to promote further economic integration development (Stepanova, 2013). On January 1, 2015, it was transformed into the Eurasian Economic Union (EAEU) and enlarged by Kyrgyzstan and Armenia. Thus, the third example is inter-regional integration agreements. With the population of around 144 million people and gross national income (GNI) per capita of 13.210 dollars US, Russia belongs to the group of high-income countries. Starting from 2012 Russia experienced a number of events, which facilitated integration of the country with the global economy and its trading relations with other countries. After more than 18 years of negotiations Russia joined the World Trade Organization. Also for the first time Russia hosted the summit meeting of the Asia-Pacific Cooperation (APEC) in Vladivostok with a number of important agreements on liberalization of trade investment and regional economic integration.

Further on, Russia launched the Common Economic Space with Belarus and Kazakhstan as well as the Customs Union. Currently the Russian share in GDP of the Customs Union makes $86 \%$ and of population is $84 \%$. Kazakhstan has $8 \%$ of GDP and $10 \%$ of population, Belarus accounts for $5 \%$ of GDP and for $5 \%$ of population. Russia has intensive trade relations with these two countries, with the Russian export making $46 \%$ of all export to Belarus and $24 \%$ of Kazakhstan. Trade of petroleum and natural gas plays an important role in Russian exports to these countries. Trade between members of the Customs Union is also facilitated by the fact that internal tariffs between members were largely eliminated. Supposedly, these events would facilitate trade activities between Russia and foreign countries. In 2013 the FDI inflows to Russia made 26.1 billion USD, a significant portion of this FDI (11.15 billion USD) came from offshore companies (EMISS database of Rosstat, 2015). Thus, around 50\% of all FDI in Russia can be regarded as returning of Russian capital. These investments are primary done into real estate, trade, manufacturing and mining. However, the share of industries engaged into innovation does not exceed 20\% of all FDI (Grasmik, 2015). The record year for FDI was 2007 and 2008 when the volumes of FDI reached 27.8 billion USD. The share of individual 
industries in FDI and investment in fixed assets made $27 \%$ in manufacturing sector, $14 \%$ in food manufacturing, $14 \%$ in transportation equipment manufacturing, $12 \%$ in nonmetallic mineral product manufacturing, $9 \%$ in chemical manufacturing, $6 \%$ in production of electrical equipment and $4 \%$ in metal manufacturing (Rosstat, 2015).

In the year 2013 the volumes of FDI to the Russian economy reached their record level of 94 bn US dollars, which put Russia for the first time in history on the third place among 20 countries with maximum volumes of FDI (UNCTAD, 2015). This happened mainly because of one large deal conducted between BP and Rosneft. Other FDI during this year came from UK (26.8\%), Luxemburg (16.5\%), Ireland (14.8\%), British Virgin Islands (13.3\%), Cyprus (11.8\%) and the Netherlands (8\%) (Trading Economics). However, expectations were that the future FDI would reach the 2013 level. Examples could be large deals such as FDI from the sovereign fund Mubadala from the United Arab Emirates, which plans to invest 7bn US dollars. Currently these expectations did not realized and the decline of FDI investment continued in 2015, the year when the global FDI reached their maximum level after the financing crisis of 2008-2009. The majority of these FDI went to USA, China and Hong Kong, followed by the Netherlands, UK, Singapore, India, Brazil, Canada and France. UNCTAD identified the low volumes of global economic growth and political risks as major reasons for the drop of FDIs to Russia in 2014. Other risks identified as barriers for investment in 2015 are currency risks and again geo-political instability as well as the decline of interest regarding FDI into fossil fuels energy sector because of the low oil prices. According to the World Bank, other reasons for decline in FDI are instability of national currency and the slow economic growth as well as low prices for oil and impacts of sanctions. Despite negative current FDI dynamic, the analytics of Forbes based on the results from large-scale survey among investors, identified Russia as the forth the most attractive for FDI country, after US, China and India.

\section{Methodology}

Our methodology was based on three-stage research. During the first stage we analyzed existing literature and identified critical factors, which influence investors decision-making process. We classified all factors to two groups of objective and subjective factors. The objective factors included variables impacting trading relations with Russia, such as impacts of economic integration or sanctions. The subjective factors included variables showing business environment of the hosting country and impacts of cultural and human factors of this environment. Based on the identified variables, we settled our data collection protocol. The second stage of research was based on in-depth qualitative interviews with Austrian, Japanese and German private companies. All these companies are operating in Russia in the sectors finance, construction, logistics, consumer products, engineering and technology. The interviews were conducted during the year 2014. We are aware that our interview results might be biased in comparison to large-scale surveys based on representative sampling. However, we tried to eliminate these biases by broadening our qualitative sample and including stakeholders from different economic sectors and different countries.

The interviews included questions on business environment, strategy, current operations, success factors, problems and procedures. All questions were open questions by providing interviewees enough room to express their opinion. The interviewees received the questionnaire before the date of interview and could select the questions to answer and to prepare themselves. Each interview lasted for approximately one - two hours. Prior to the interviews we asked opinion of the stakeholders if they would agree with the publication of results from interviews in an aggregated way. The interviews were conducted in a way that the response was spontaneous and reflected the perceptions of the respondent, which allowed us to limit the influence of the interviewer on the results (Hox and de Leeuw, 2002). The questions on objective factors included business environment within the Eurasian region, main uncertainties of development within the next three to five years, expect growth and how trade conditions changed with the formation of the Customs Union and if these changes were noticeable.

The questions on subjective factors included perceptions of influence of region, of unique features of this country from the point of view of business perspective, factors which facilitated operations within the region and which made this country to be more attractive for investment then other regions as well as perceptions of uncertainty of the regulatory and political environment. The questions were also focused on perceptions of 
procedures, namely, with which kinds of special procedures it was necessary to deal when establishing business within the area, special construction permits, problems with registration of property, special requirements for arranging credits from financial institutions and input provides. These questions also included perceptions about regulations to protect investors and impacts of these regulations on business, if they slowed down or speeded up the business, what are the perceptions of complexity of taxation also in comparison to the head quarter country, of special features of contracts and of insolvency procedures. They also included perceptions of risks and problems such as visible and hidden risks as well as potential sources of risks, major obstacles for business and barriers for trade as well as perceptions of barriers for doing business in this area.

During the third stage of research we collected perceptions and concerns about barriers for FDI in the workshop "Trade Policy Regimes", which was organized to discuss trade relations between the Eurasian region and the European region. The workshop took place on the $6^{\text {th }}$ and $7^{\text {th }}$ of July 2015 at IIASA, Laxenburg, Austria. Stakeholders from policy, science and private sector communities from Austria, Azerbaijan, Belgium, Finland, Germany, Iceland, Kazakhstan, Russia, Ukraine and a number of international organizations were present $^{1}$ to discuss trade policies, conditions and practices in the Eurasian region. Additionally the scripts of interviews were analyzing with the help of such text mining programs as INVivo. These programs allow to search for frequency of key words in interviews and thus to understand the dominating discourses. The application of INVivo showed that key words, associated with such types of risks as political and regulatory risks, were used most frequently. At the same time key words associated with such risks, as force majeur circumstances, were almost not applied by interviews. Further on, we applied INVivo program on the text of the protocol with stakeholders' elicitations, which were collected during the workshop. Application of this additional analysis method allowed us to validate the results, which we gained during interviews and the workshop.

\section{Results}

Our results allowed us to identify a number of objective and subjective factors, which influence decisionmaking process on FDI in Russia. We derived our data from existing literature on trading relations and barriers for FDI and elicitations from workshops participants. Further on, we validated our results through data, which we received from interviews on perceptions of likelihood and seriousness of concern about risks for FDI in Russia. We identified the following objective factors connected with the issue of trading across borders, including documents requirements, custom procedures, port operations and existing infrastructure, which might lead to extra costs and delays. The Ease of Doing Business covers time and costs associated with logistical processes for exporting and importing goods and refer to a case study scenario of a warehouse in the largest business city of the country. Sadly, according to this index Russia stands on the place 170 out of 189 economies, even though there was a number of reforms to make trading across borders easier such as the reduction of the number of documents needed for transactions and lowering associated costs in 2012 or implementation of electronic system for submission of export and import documents and reduction of physical inspections in 2014. Here the most striking factor is the costs to export and import, including the border compliance, which makes around 1.125 dollars US in comparison to 219 dollars US average for Europe and Central Asia.

Sanctions, and mainly their intransparent character, were mentioned as another factor, which impacts FDI. However, the major perception was that the sanctions were a part of political and diplomatic discourse and

\footnotetext{
${ }^{1}$ The Russian participants were represented by the following organizations: Eurasian Economic Commission, JSC "Severstal", Gaidar Institute for Economic Policy, Eurasian Development Bank, Ministry of Economic Development of the Russian Federation, Russian Association of Public Relations, Institute for Economic Forecasting, Center for Economic and Financial Research, Permanent Mission of the Russian Federation to the International Organizations in Vienna, Trade Mission of the Russian Federation in the Republic of Austria. The participants from the European Union countries were represented by the DG Trade of the European Commission, European Council of Foreign Relations, Frankfurt School of Finance and Management, University of Helsinki, Bank of Finland's Institute for Economies in Transition, Centre for European Policy Studies (CEPS), University of Iceland, Vienna Institute for International Economic Studies, Austrian National Bank, Joint Vienna Institute, Vienna Institute for International Economic Studies. The participants from other countries were represented by employees of IIASA, Institute of Economics and Forecasting in Ukraine, Ministry of Economy and Budget Planning of the Republic of Kazakhstan, International Institute of Economics and Law of Kazakhstan, Kazakhstan Economic University, National Chamber of Entrepreneurs of Kazakhstan, Center for Economic and Social Development of Azerbaijan
} 
did not have much impact on the everyday operations. As one interviewed stakeholder mentioned "we know that the Japanese government has a list of sanctioned Russian individuals, but this list is not public. So it does not have any pragmatic impact".

The mentioned current trade barriers included comparative advantages and of how trade barriers are impacting these advantages. For example, Japanese companies are making their investment decisions based on existing business opportunities in different potential markets and with dynamics of trade agreements. If a market provides opportunities for growth, then a company is willing to adjust to the regional features and is able to cover the additional costs. Regarding the trade dynamics, an interviewee from Japan mentioned that companies are closely following up the continuously evolving trade agreements' field, where various ongoing negotiations of free trade agreements and other arrangements are shaping the global trade environment.

The participants of the IIASA workshop also mentioned non-tariff barriers, however, rather as an impact on the trade flows in the Customs Union, then a barrier for FDI. They called them as "asymmetric barriers" when a trade barrier is imposed by at least one member of the Customs Union and when there is at least one member, which does not impose such barrier. The experts' elicitations show that reduction of non-tariff barriers may lead to an increase in efficiency, output and productivity within the Customs Union.

Our results allowed us to identify four types factors, which shape subjective risk perceptions. These are political, revenue operational and regulatory risks. The political risks were mentioned most frequently and by all interviewed stakeholders. When they spoke about political risks they mainly referred to instability of regulatory environment and weakness of the government to implement regulations. One of the interviewees was even describing the current political situation as "controlled confusion", namely "this confusion is generated by purpose. It serves those that either have the power dominance - or those that want to disrupt current regimes. The middle class will be the group that will lose most in this situation". Also results of interviews showed that perceptions of political risks are gaining their important and these types of risks are perceived as the most serious and likely for FDI. The perceptions of revenue risks were connected with the limited availability of local or international capital and the currency fluctuations, which increased the real costs and have reflections on pricing. Currency uncertainty also requires larger cost puffers, which raise the volumes of investment. Our interviewees mentioned that financing and re-financing becomes increasingly more difficult for Russian companies and foreign companies active in Russia.

When stakeholders spoke about operational risks, they mainly described the lack of industrial ecosystem, when the local industrial ecosystems are not developed enough to provide production with right quality and type of raw materials and components, thus large amount of components and means has to be imported. Operational risks also often include the lack of local firms offering maintenance services, the lack of skilled and experienced local staff and the limited experience of grid operator with renewable electricity sources. The perceptions of regulatory risks included the lack regulations as well as complexity and corruption of bureaucratic procedures, complex processes and long time frames for obtaining permits and licenses for projects and instability of national regulations, such as regulations to start business, dealing with construction permits, registering property, protection of investors, enforcing contracts, resolving insolvency among other variables.

Objective facts show that Russia is doing pretty well on the majority of these indicators; however, subjectively investors perceive these risks as most serious and likely to happen. For example, it ranks above the regional average for starting business and for resolving insolvency Russia ranks the place51 in comparison to China (55), Brazil (62) and Europe and Central Asia average (74). It takes in Russia 310 days in average to enforce contracts in comparison to the 481 days for the European and Central Asian average and the costs of resolving standardized disputes are also low. Globally, Russia stands on the place 5 on the ease of enforcing contracts; in comparison to the place 50 for the regional European and Central Asian average. Also the country ranks the place 8 for registering property, in comparison to the rank 49 for regional average. The high ranking is mainly due to the regulations, which were developed the last years and made registration of property transfers easier by computerizing land registries, introducing time limits for procedures and setting low fixed fees. Improvements are necessary in such areas as protecting minority investors, which relates to the ability of companies to raise capital they need to grow, to innovate, diversify and compete, where Russia 
ranks the place 66 in comparison to the 46 for the regional average. The dealing with construction permits still remains a problematic area where Russia ranks the place 119, which still requires passing 19 procedures and takes in average 264 days. Interviews showed that five kinds of risks were perceived as being most likely and serious threat for FDI in Russia. Four of these risks are subjective risk perceptions connected with environment for doing business in Russia itself. Only one risk - currency risk - is perceived among external factors as being a threat for investment (figure 1).

The political risks, as the leading role of politicians in the business context, were mentioned most frequently. At another side, it was also connected with perceived political instability. This type of risk was also closely connected with existing regulatory structure and capacities of the government to implement regulations. Other frequently perceived risks were operational and revenue, which were connected with low economic growth and malfunctioning of investment market. Interviewees were even mentioning, "The demand on the Russian market became too low", that "the economy does not support our type of business" or that "current business can cover only costs of distribution".

\section{Figure 1: Perceptions of risks for FDI in Russia}

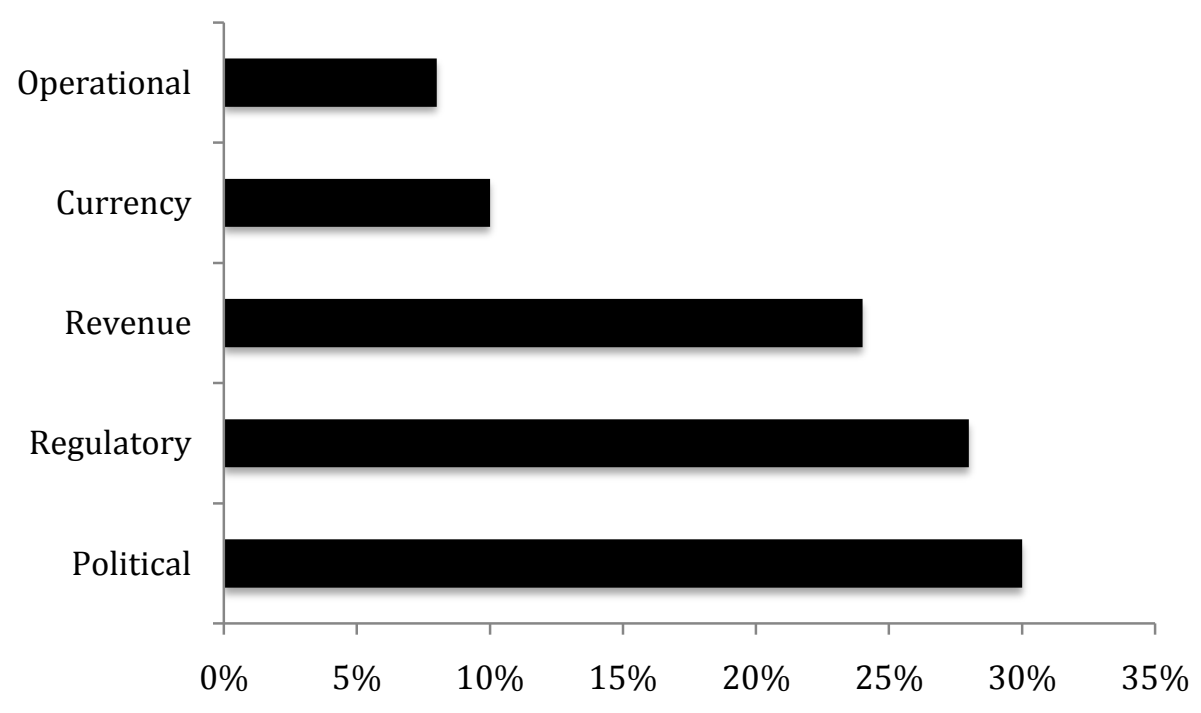

The perceptions of regulatory risks are also connected with the lack of industrial ecosystem regulations. One of the most common perceived barriers was the requirement to use contribution of local product and service providers however the principle of joint venture with local partners were perceived positively as a way to gain knowledge on specifics of the Russia market and local procedures. For instance, one of interviewees spoke about how joint ventures could address existing political and regulatory risks as following: "The tendering process is here very difficult for us. The government is providing us with a very detailed specification and the budget, called "smeta", which is a feature of central planned economy. This is extremely difficult for a foreign player to fit with this budget. The local players know how to get additional costs accepted during the implementation process, which lead to significant increase of the costs of the project, low efficiency and asymmetric information for foreign players giving advantages for local players". During the last years Russia also made significant progress by addressing regulatory risks. In the year 2015 Russia ranked the place 21 in the Ease of Doing Business, which was above the European and Central Asia average rank (55) and much better than China (84), Brazil (116) or India (130). But some of the existing regulations such as dealing with construction permits, protecting minority investors or customs regulations, still need significant simplifications and are perceived as regulatory risks by FDI investors.

The results of interviews show that the majority of risks perceived as a threat for FDI in Russia are connected with subjective risks perceptions of environment within the country, as political, regulatory, revenue or operational risks. These risks were a typical feature of the Russian economy in the last decades and there is 
no evidence that they were affected by creation of the Eurasian Customs Union or current international relations. Political risks relate to the leading role of politicians in the business context. Political risk is also often understood as the low level of political stability, lack of support from local government, poor rule of law and institutions and poor governance. There is a clear link identified by previous research between political factors and FDI. Harms and Ursprung (2002) identify that autocracies are perceived with a greater risk of policy reversals and therefore attract less FDI. However, further evidence is controversial. For instance, Kolstad and Villanger (2008) find that the democratic structures matter only for FDI in developing countries and in specific sectors, such as services. Adam and Filippaios (2007) find out that there is a link between civil and political liberties and that FDI go rather to the countries with low civil but high political liberties. Also it seems that the countries with lower levels of democracy receive higher FDI (Kim, 2010) but these results could be biased by in proportionally high investment flows to China. However, there is a homogenous opinion across several studies that political stability is extremely important. Tuman and Emmert (1999) find that certain types of regime changes, such as revolutions, have negative impacts on FDI.

The analysis of our results on political risks and their comparison with available evidence shows that the majority of perceptions about political risks emerge from existing asymmetries on the market. From the business perspective, the challenges will emerge when political decision-making has dominance on business environment. It can also emerge when some economic players have a dominant role on the market or when one region or regulation has a dominant role.

Our results correspond with available evidence from the global studies conducted by UNCTAD (2015), World Bank (2013), World Economic Forum (2014) or Bleyzer Foundation (2002) on the impacts of uncertainties connected with regulatory and political risks in Russia. They also identify currency risk as an important barrier, which appeared during the last years but in contrary to the global studies, our research did not identify that force majeure risks, such as wars or local conflicts, are perceived as a likely risk for FDI investment at a current time period in Russia. Our results allow the statement that even though significant progress was done during the last years to mitigate regulatory risks for investment and to improve investment climate, still significant work should be done to address such regulatory risks as the process of issuing construction permits or complex customs regulation. Also further efforts would allow addressing existing market asymmetries and the power relationship between business and politics by addressing existing uncertainties and creating more stable investment environment.

Acknowledgment: we are especially grateful to experts and practitioners who contributed their time and expertise by participating in interviews. These are Thomas Birtel (CEO, Strabag), Yogo Konno (Chief Economist, Research Institute of Mizuho Bank), Astrid Kratschmann (Erste Bank), Mr. Joachim Dudey, Director Sales \& Financing, WTE Wassertechnik GmbH (Germany), TomoakiNishitani (Director, Institute for International Economic Studies, Toyota Motors), Toshikazu Endo (Director, Institute for Russian and NIS Economic Studies), JussiTuisku (CEO, Ruukki Russia) and Reijo Valo (CEO, East Office of Finnish Industries Ltd.). We are also grateful to participants of the experts' workshop, which was organized in July 2014 at IIASA, who contributed their time and expertise being generous with comments and ideas during the workshops discussions. We also would like to acknowledge the funder of the project "Challenges and Opportunities of Economic Integration within a Wider European and Eurasian Space", the Russian Academy of Sciences which made organization of the workshop and this research possible.

\section{References}

Adam, A. \& Filippaios, F. (2007). Foreign direct investment and civil liberties: A new perspective. European Journal of Political Economy, 23(4), 1038-1052.

Alesina, A., Spolaore, E. \& Wacziarg, R. (2005). Trade, Growth and the Size of Countries. Handbook of Economic Growth, Volume 1B. Edited by Philippe Aghion and Steven N. Durlauf. Elsevier.

Azam, M. \& Ahmed, A. (2015). Role of human capital and foreign direct investment in promoting economic growth: Evidence from Commonwealth of Independent States. International Journal of Social Economics, 42(2), 98 - 111.

Bleyzer Foundation. (2002). The Bleyzer Initiative: Completing the Economic Transition in FSU Countries, The Bleyzer Foundation, Kiev. 
Blonigen, B. (2001). In search of substitution between foreign production and exports. Journal of International Economics, 53, 81 - 104

Brainard, S. (1997). An empirical assessment of the proximity - concentration trade-off between multinational sales and trade. American Economic Review, 87, 520-544

Busse, M. \& Hefeker, C. (2007). Political risk, institutions and foreign direct investment. European Journal of Political Economy, 23(2), 397-415

Campos, N. \& Kinoshita, Y. (2002). Foreign Direct Investment as Technology Transferred: Some Panel Evidence from the Transition Economies. The Manchester School, 70(3), 398-419

Corcoran, A. \& Gillanders, R. (2015). Foreign direct investment and the ease of doing business. Review World Economics, 151, 103-126

Dunning, J. (1998). Globalization and the new geography of foreign direct investment. Oxford Development Studies, 26(1), 1998

Dunning, J. (1973). The determinants of international production. Oxford Economic Paper, 25, 289-336

Egger, E. \& Winner, H. (2005). Evidence on Corruption as an incentive for Foreign Direct Investment. European Journal of Political Economy, 21, 932-952.

Eicher, T. S., Papageorgiou, C. \& Raftery, A. E. (2011). Default Priors and Predictive Performance in Bayesian Model Averaging, with Application to Growth Determinants. Journal of Applied Econometrics, 26(1), 30-55

Hall, R. \& Jones, C. (1999). Why Do Some Countries Produce So Much More Output per Worker than Others? The Quarterly Journal of Economics, 114, 83-116.

Harms, P. \& Ursprung, H. (2002). Do Civil and Political Repression Really Boost Foreign Direct Investment? Economic Inquiry, 40(4), 651-663

Hox, J. \& de Leeuw, E. (2002). The Influence of Interviewers' Attitude and Behavior on Household Survey Nonresponse: an International Comparison. In R.M. Groves, D.A. Dillman, J.L. Eltinge, R.J.A. Little (Eds.) (2002). Survey Nonresponse. New York: Wiley.

Grasmik, K. (2015). Alternative Assessment of Volume and Industry Structure of Foreign Direct Investment in Russia. Studies on Russian Economic Development, 26(3), 218-224

Iwasaki, I. \& Tokunaga, M. (2014). Macroeconomic Impacts of FDI in Transition Economies: A Meta-Analysis. World Development, 61, 53-69.

Janjua, P. \& Samad, G. (2007). Intellectual Property Rights and Economic Growth: The Case of Middle Income Developing Countries. The Pakistan Development Review, 46(4), Papers and Proceedings PARTS I and II Twenty-third Annual General Meeting and Conference of the Pakistan Society of Development Economists Islamabad, March 12-14, 2008 (Winter 2007), pp. 711-722

Jayasuriya, D. (2011). Improvements in the World Bank's ease of doing business rankings: do they translate into greater foreign direct investment inflows? World Bank Research Working Paper, 2011

Jude, C. \& Levieuge, G. (2014). Growth Effect of FDI in Developing Economies: the Role of Institutional Quality. DR LEO 2013-11. 2014.

Kim, H. (2010). Political Stability and Foreign Direct Investment. International Journal of Economics and Finance, 2(3).

Klapper, L., Laeven, L. \& Rajan, R. (2006). Entry Regulation as a Barrier to Entrepreneurship. Journal of Financial Economics, 82, 591-652.

Kobrin, S. (2005). The determinants of liberalization of FDI policy in developing countries: 1991-2001. Transnational Corporations, 14(1), 67-103

Kolstad, I. \& Villanger, E. (2008). Determinants of foreign direct investment in services. European Journal of Political Economy, 24(2), 518-533.

Komendantova, N., Patt, A. \& Williges, K. (2011). Solar power investment in North Africa: Reducing perceived risks. Renewable and Sustainable Energy Reviews, 15(9), 4829-4835 (December 2011).

Lawless, M. (2009). Tax complexity and inward investment. Research Technical Papers 5/RT/09, Central Bank of Ireland.

Lucke, H. \& Eichler, S. (2016). Foreign direct investment: the role of institutional and cultural determinants. Applied Economics, 48(11), 2016.

Martinez-San, R., Bengoa, M. \& Sanchez-Robles, B. (2015). Foreign direct investment, trade integration and the home bias: evidence from the European Union. Empirical Economics, Springer, 2015

Mkrtchyan, A. \& Gnutzmann, H. (2014). Mutual Protectionism? An Assessment of the Eurasian Customs Union. Department of Economics, European University Institute 
Neary, J. (2009). Trade costs and foreign direct investment. International Review of Economic Financing, 19, $207-218$

Pfaffermayer, M. (1996). Foreign outward direct investment and exports in Austrian manufacturing: substitutes or complements? Weltwirtschaftliches Archiv, 132, 501-552

Rosstat, (2015). Russia 2015 Statistical Pocketbook. Federal State Statistics Service (Rosstat)

Slovic, P. (1987). Perception of Risk. Science, 236, 280-285

Stepanova, A. (2013). Eurasian Union and Ukraine. Monography, Moscow, Russia (In Russian).

Tuman, J. \& Emmert, C. (1999). Social Science Quarterly Vol. 80, No. 3 (September 1999), pp. 539-555

UNCTAD. (2015). World Investment Report: 2014. New York and Geneva: United Nations Conference on Trade and Development, New York and Geneva.

UNCTAD. (2014). Foreign Direct Investment Data Base: United Nations Conference on Trade and Development, New York and Geneva.

UNCTAD. (2014). World Investment Report: 2013. New York: United Nations Conference on Trade and Development, New York and Geneva.

UNCTAD. (2010). World Investment Report 2010, United Nations Conference on Trade and Development, New York and Geneva.

UNCTAD. (2003). World Investment Report: 2003. New York and Geneva: United Nations Conference on Trade and Development, New York and Geneva.

UNCTAD. (2002). World Investment Report: 2002. New York and Geneva: United Nations Conference on Trade and Development, New York and Geneva.

World Economic Forum. (2014). Global Risks Report 2014. Geneva.

World Bank. (2013). Doing Business 2014: Understanding Regulations for Small and Medium-Size Enterprises. Washington, DC: World Bank Group. 